\title{
Erratum to: Ankylosing spondylitis in Ireland: patient access and response to TNF- $\alpha$ blockers
}

\author{
Aamir Saeed • Mumtaz Khan • Musaab Elmamoun • \\ Mary Brady • Siobhan Morrissey • \\ Alexander Duncan Fraser
}

Published online: 2 March 2011

(C) Springer-Verlag 2011

Erratum to: Rheumatol Int

DOI 10.1007/s00296-011-1797-y

The co-authors names were skipped out in the author group of published online article. Here is the correct list of author group and their affiliations.

The online version of the original article can be found under doi:10.1007/s00296-011-1797-y.

\footnotetext{
A. Saeed $(\bowtie) \cdot$ M. Khan $\cdot$ A. D. Fraser University of Limerick Medical School, University of Limerick, Limerick, Ireland e-mail: modelian@gmail.com

M. Elmamoun - M. Brady · S. Morrissey · A. D. Fraser Department of Rheumatology, Mid-Western Regional Hospitals, St. Nessan's Regional Orthopaedic Hospital Croom, Co., Limerick, Ireland
} 